Actualité internationale de la littérature critique sur l'art contemporain

45 | 2015

CRITIQUE D'ART 45

\title{
Etel Adnan
}

\section{Elisabeth Lebovici}

Translator. Simon Pleasance

\section{(2) OpenEdition}

\section{Journals}

Electronic version

URL: http://journals.openedition.org/critiquedart/19171

DOI: $10.4000 /$ critiquedart. 19171

ISBN: 2265-9404

ISSN: 2265-9404

\section{Publisher}

Groupement d'intérêt scientifique (GIS) Archives de la critique d'art

\section{Printed version}

Date of publication: 4 November 2015

ISBN: $1246-8258$

ISSN: 1246-8258

\section{Electronic reference}

Elisabeth Lebovici, «Etel Adnan », Critique d'art [Online], 45 | 2015, Online since 04 November 2016, connection on 20 April 2019. URL : http://journals.openedition.org/critiquedart/19171; DOI : 10.4000/ critiquedart.19171

This text was automatically generated on 20 April 2019.

EN 


\section{Etel Adnan}

\section{Elisabeth Lebovici}

Translation : Simon Pleasance

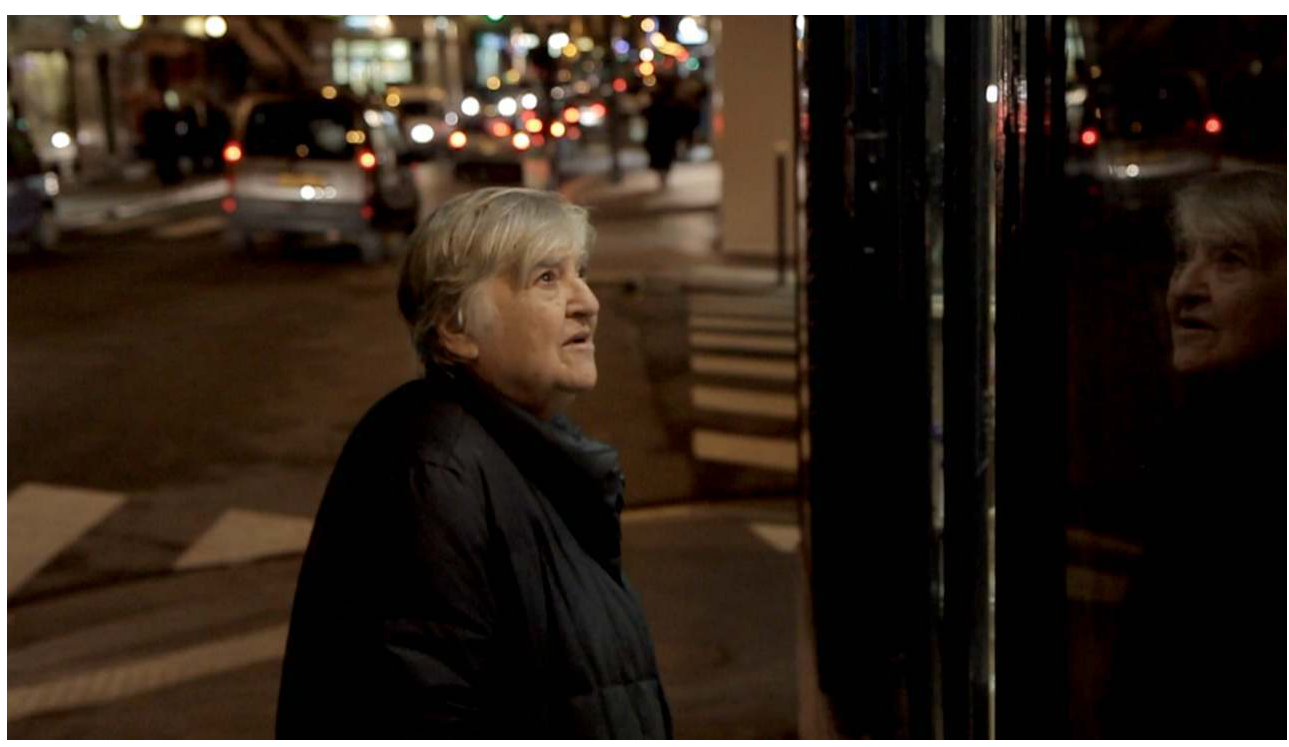

Etel Adnan @ Pikrle Jones, with courtesy of the artist

1 Etel Adnan (1925-) paints and writes. Labels such as "poet" or "painter" do not concern people belonging to "her generation" of girls raised in Beirut, which was then under French rule. "My mother was Greek, from Smyrna (now Izmir). I grew up speaking Greek, I spoke Arabic in the street, and I learnt French, which was obligatory at the school run by nuns. My father was a Muslim Syrian, he spoke Turkish with my mother. I lost a simple and clear identity but acquired an immense cultural wealth by having two religions and three languages at home." ${ }^{1}$ Etel Adnan speaks and writes in Arabic, French, and English.

2 Her trilingualism finds expression in her life. For a long time she has moved between three home bases. From Beirut she went to Paris in 1949-50, thanks to a three-year study grant. "It was the postwar period, which was neither war, nor peace." She lived on her own in the American pavilion in the Cité Universitaire. She read Jean-Paul Sartre, a 
"revelation": for her, he unravelled the link between morality and religious belief; she discovered museums, concerts, bookshops, and the classes given by Gaston Bachelard and Etienne Souriau at the Sorbonne. From Paris she travelled to California in 1955 to study philosophy at Berkeley, and then at Harvard. She never finished her PhD, but she found a teaching job at the Dominican College in San Rafael (California), where she taught philosophy between 1958 and 1972. "Everything was in ferment everywhere and all at the same time. For me, that was just as important as the pre-Socratics and the Russian avantgardes." Jazz, dance, the social revolution, 1968, the movements for civil rights and women's rights... It was by shifting to English, and espousing the underground resistance to the Vietnam war, as expressed by what young people were saying, that Etel Adnan became an "American poet". ${ }^{2}$ This poet-in-the-making, writing in English, then settled in Sausalito, in California, just north of San Francisco, after 1977. Her career was conducted under the aegis of public readings and an oral tradition. This is an experience that she is continuing today in Paris, with the young people with whom she writes and reads. The Lebanese sculptress and editor, Simone Fattal, of Syrian extraction, with whom she has shared her life for 40 years, has for her part published and translated many poets into English, in her California publishing house, Post-Apollo Press.

3 In California, in 1959 or thereabouts, Etel Adnan taught the writings of painters-as "an activity of thought", which she saw as distinct from theory-when the head of the painting department (painting was a discipline taught at American universities) gave her pencils and paper and set her to work. "I made the leap." Etel Adnan became a painter. Her Cézanne an Montagne Sainte Victoire was Californian. It was expressed in two languages, that of the conquered Indian people and that of the conquering Spaniards: it was called Mount Tamalpais. The magic mountain was-and is-forever changing, because of the light and "also because you have changed." This adventure of the eye found its narrative expression in the book Journey to Mount Tamalpais. ${ }^{4}$ And it recurs in these small pictures-their format is due to a chronic back problem, as much as to the reference to the paper page-which are so many celebrations of an experience that was as physical as it was spiritual.

4 "One moves forward by practicing: by working, by teaching, by writing. This is a confrontation which involves us." So Sitt Marie Rose, a feminist tale written in one and a half weeks in Paris, during the 1977 war in Lebanon, was immediately published by the Editions des femmes. It translates into words the amorous gestures of Marie Rose for the "excluded and encircled" Palestinians. And in French as Apocalypse Arabe, which Etel Adnan herself translated into Arabic. In the meantime she returned to a Beirut in turmoil, between 1972 and 1975, where she was responsible for the five weekly cultural pages of the newspaper Al Safa.

5 For Adnan, writing is still a way of taking part in politics, "that is to say, in the world and in the management of the world." ${ }^{5}$ With exhibitions in New York, London, Beirut, Paris and Dubai, her joy in painting filled a room at documenta 13, while, for a month and for two hours every day, Etel Adnan waited for her interlocutors to introduce themselves in the Chinese restaurant in the municipal gardens. By painting and writing, she relaunches the present moment of an encounter which we will henceforth never be able to do without. 


\section{NOTES}

1. Taken from the Etel Adnan seminar at the EHESS, "Something You Should Know ", 21 March 2012.

2. To look at the sea is to become what one is: An Etel Adnan Reader. Ananthology of her essays, fiction, inter-genre, poems and translations was published by Nightboat Books (2014).

3. Excerpt of an interview with Léonore Chastagner.

4. Translated into French in 2014, Voyage au Mont Tamalpais, Paris : Manuella Editions.

5. Her poems have at times been set to music (by Gavin Bryars, Henry Threadgill and Tania Leon); she also wrote the French part of the Bob Wilson opera, The CIVIL Wars (1985), and has written two plays. 